\title{
Incidence of virus Y Strains and Effect of Infection on the Productivity of Potato Tubers.
}

\author{
Rania Z. Ahmed ${ }^{\text {a }}$; I.A.M. Ibrahim ${ }^{\text {b }}$; H.M.S. Hassan ${ }^{\text {c }}$; D.A.El-Wakil ${ }^{\text {d }}$ \\ Jazan University, College of Science ,Kingdom of Saudi Arabia ${ }^{\text {a,d }}$, \\ Cairo University, Egypt ${ }^{\mathrm{b}, \mathrm{c}}$
}

\begin{abstract}
Field survey studies were conducted during three growing seasons to study the prevalence and distribution of PVY strains infecting potato in different locations at Behairah, Sharkia and Menoufia governorates (Egypt). The most common symptoms were different types of mosaic, leaf crinkling, necrosis and leaf drop streak. Four virus strains namely: tobacco veinal necrosis strain $\left(P V Y^{N}\right)$, common strain $\left(P V Y^{O}\right)$, stipple streak strain $\left(P V Y^{C}\right)$ and potato tuber necrotic ring spot $\left(P V Y^{N T N}\right)$ were detected using DAS-ELISA. At the nile growing season $P V Y^{O}$ was the most prevalent virus (63.5\%) followed by $P V Y^{N}(25 \%) . P V Y^{N}$ had the highest frequency $(67 \%)$, followed by $P V Y^{\circ}(25.7 \%)$ at the winter growing season. While at summer growing season, $P V Y^{N}$ and $P V Y^{O}$ had the most prevalent viruses (36.7\%). Agar double diffusion test was used to confirm the identity of the isolated PVY strains. The Egyptian PVY strains reacted strongly with the specific antiserum for each strain forming a prominent precipitin line. Productivity of potato cultivar Spunta to infect with virus strains was conducted in the farm of Benha, Qalubia decreased by $22.6 \%$ to $50.5 \%$ according to the strain as compared with control.
\end{abstract}

\section{Introduction}

PVY is the type member species of the family potyviridae (Galis et al., 2000). PVY is considered one of the most damaging potato viruses causing significant yield losses because the infection with PVY spread easily and the yield reduction reached to $80 \%$ in potato and 39-75\% in tobacco (DE Bokx and Huttinga, 1981) depending on the PVY strains, cultivars and time of infection. Primary symptoms of PVY are necrosis, mottling or yellowing of leaflets, leaf dropping or sometimes premature death. These viruses display a monopartite genome constituted of positive sense single stranded RNA bordered by two distal non-translated regions (Hollings and Brunt, 1981) and translated into a polyprotein which is processed by three viral proteases into nine functional proteins (Riechmann et al., 1992). PVY is wide spread all over the world and causes economically important disease not only to solanaceous crops but also too many solanaceous weeds (Glais et al., 2002;Quintero-Ferrer and Karasev, 2013 ).

The PVY isolates have classically been divided into three main strains (DE Bokx and Huttinga, 1981). The common strain or ordinary strain $\left(\mathrm{PVY}^{\mathrm{O}}\right)$ induced mainly severe systemic crinkle symptoms, rugosity of leaf drop, streak on potato, systemic necrosis on Physalis floridana, and systemic mottling on tobacco plants. The tobacco veinal necrosis strain $\left(\mathrm{PVY}^{\mathrm{N}}\right)$ Induced severe systemic veinal necrosis on tobacco, systemic mottling on Ph. floridana and very mild mottling on almost all potato cultivars. The stipple streak strain $\left(\mathrm{PVY}^{\mathrm{C}}\right)$ isolate evoke systemic mosaic or stipple streak symptoms in susceptible cultivars bearing the Nc resistance gene, tobacco plants reacted with vein banding symptoms while the symptoms on Ph. floridana were systemic necrosis (Blanco-Urgoiti et al., 1998; Chikh et al., 2013 ) .

Emergence of new particular PVY isolates was detected. Inducing new diseases in potato crop. Such as: PVY ${ }^{\mathrm{NTN}}$ first detected in Hungary in 1984 (Beczner et al., 1984). Since then it has been detected in potato tubers from tubers (Le Romancer and Kerlan, 1997; Gorsane et al., 2001). Now considered more aggressive isolate of $\mathrm{PVY}^{\mathrm{N}}$, it is the causal agent of the potato tuber necrotic ring spot disease (PTNRD) which is characterized by superfiel bows, first protruding then later becoming sunken and necrotic (Kus, 1990). $\mathrm{PVY}^{\mathrm{N}}-$ Wi, found in Poland in 1984 was described as differing in virulence and aggressiveness from the older PVY isolates (Chrzanowska, 1991) and was shown to be serologically related to $\mathrm{PVY}^{\mathrm{O}}$ isolates (Chrzanowska, 1994). $P V Y^{Z}$ was found in Britain in 1984, differing from $P V Y^{\mathrm{O}}$ and $P \mathrm{PV}^{\mathrm{C}}$ by its ability to overcome the hypersensitive genes Nytbr and $\mathrm{Nc}$ and furthermore targeting an hypothetical Nz gene (Kerlan et al., 1999).

Surveys of commercial seed potato yields for virus diseases in Manitoba established that potato virus $\mathrm{Y}$ is of concern in seed potato production, the samples collected (2000 to 2001) contained PVY. Further analysis of the $\mathrm{PVY}$ - positive samples by a duplex RT-PCR indicated that $37.5 \%$ contained $\mathrm{PVY}^{\mathrm{O}}$ and $63.5 \%$ contained $\mathrm{PVY}^{\mathrm{N}}$ (Singh et al., 2003).

The potato virus Y strains incidence during 2001 to 2003 in Washington and Oregon, as evidenced by more infected cultivars, sites of seed origin, and number of seed growers providing infected seed lots. Totals of 960 and 286 certified potato lots, there was a dramatic increase in seed lots with the PVY (N:O) strain from 
2002 to 2003, in contrast to $\mathrm{PVY}^{\mathrm{O}}$, which causes yield reduction, also causes internal and external damage to tubers, making them unmarketable (Crosslin et al., 2006).

Agar gel double diffusion can be used for detection of elongated viruses in purified preparations and in plant extracts (Ouchterlony, 1962).

The objective of the present work is to determine the distribution and prevalence of PVY strains in different locations at 3 governorates in Egypt based on external symptoms and using DAS-ELISA. Agar double diffusion test was identity of the isolated PVY strains. Productivity of potato PVY infected cultivar Spunta was conducted also.

\section{Materials And Methods}

Incidence of PVY strains affecting potato plants in some governorates

Field survey studies were conducted during three growing seasons to study the prevalence and distribution of PVY strains infecting potato in different locations at Behairah, Sharkia and Menoufia governorates (Egypt). (Solanum tuberosum) cultivars Nicola and Spunta. The most common symptoms detected in the field were different types of mosaic, leaf crinkling, necrosis and leaf drop streak. Evaluation of disease incidence was based on external symptoms and serological diagnosis was carried out using DAS-ELISA.

The virus strains were detected in naturally infected potato plants using specific monoclonal antibodies for $\mathrm{PVY}^{\mathrm{N}}, \mathrm{PVY}^{\mathrm{O}}, \mathrm{PVY}^{\mathrm{C}}, \mathrm{PVY}^{\mathrm{NTN}}$ and polyclonal antibodies of PVY for all isolates by DAS-ELISA (Kindly provided by Prof. Dr. Robert Burns, Edinburgh University, Scotland).

During three growing season, 232, 237 and 79 samples were collected during nile, winter and summer seasons respectively. Different types of virus like symptoms were collected in plastic bags and stored at $4^{\circ} \mathrm{C}$ until used for viral detection. The samples were indexed by DAS-ELISA against PVY strains.

\section{Serological detection of PVY strains}

\section{A). Direct double antibody sandwich (DAS-ELISA):}

The direct double antibody sandwich (DAS-ELISA) was used for virus detection as mentioned by Clark and Adams (1977). Four monoclonal antibodies were used: MAb1 specific to PVY ${ }^{\mathrm{O}}$ strain, MAb2 specific to $\mathrm{PVY}^{\mathrm{N}}$ strain, MAb3 specific to $\mathrm{PVY}^{\mathrm{C}}$ strain, MAb4 specific to $\mathrm{PVY}^{\mathrm{NTN}}$ strain and polyclonal antibody to all PVY strains. Positive samples and all antibodies were kindly provided by. Dr. Robert Bruns, Edinburg University, Scotland.

Polyethylene microtitre plates (flat bottom type) were coated with specific immunoglobin $200 \mu \mathrm{l} /$ well $\mathrm{IgG}$ at the rate $1 \mu \mathrm{g} / \mathrm{ml}$ in coating buffer $\mathrm{pH} 9.6$, then plates were incubated at $37^{\circ} \mathrm{C}$ for $2 \mathrm{hr}$. Plates were washed three times with PBS-Tween 20 buffer $\mathrm{pH}$ 7.4, 3 min. The tested samples were prepared by grinding one gram of leaf and petiole tissues in $4 \mathrm{ml}$ phosphate-buffer saline PBS pH 7.4, then $200 \mu \mathrm{l}$ were added per well and 2 wells from healthy plants as a negative control and from diseased plants as a positive control followed by incubation at $4^{\circ} \mathrm{C}$ overnight. Plates were washed 3 times as mentioned above. Alkaline phosphatase conjugated IgG was added with rate of $200 \mu \mathrm{l} /$ well at a dilution of 1:1000 in conjugate buffer and then incubated at $37^{\circ} \mathrm{C}$ for $3 \mathrm{hr}$. Plates were washed 3 times as mentioned above and then $200 \mu \mathrm{l}$ of the substrate (P-nitrophenyl phosphate) prepared immediately before use in substrate buffer with a final concentration of $1 \mu \mathrm{g} / \mathrm{ml}$ were added for each well. The plates were incubated at room temperature for one hour or as long as it necessary to develop reaction. The reaction was stopped by adding $50 \mu \mathrm{l} 3 \mathrm{M} \mathrm{NaOH}$ to each well. Plates were examined to measure the optical density (O.D.) at $405 \mathrm{~nm}$-wave length with a spectrophotometer (Dynatech laboratory MR7000). The positive results were recorded over to 2 time fold a negative control and less than that is considered as a negative reaction.

\section{B). Agar double diffusion test:}

Serological detection and distinction of the virus strains was done by ouchterlony double-diffusion test according to Purcifull and Batchelor (1977). $4 \mathrm{~g}$ agar was added to $300 \mathrm{ml}$ of distilled water in a beaker and autoclaved for $5 \mathrm{~min}$ at $121^{\circ} \mathrm{C}$, then $5.0 \mathrm{~g}$ sodium azide was added to the molten agar and mixed well. $2.5 \mathrm{~g}$ SDS was added to $100 \mathrm{ml}$ of hot distilled water and added to the agar-azide mixture. Bring up to a volume of $500 \mathrm{ml}$ with blot distilled water and mixed well. Petri dishes were placed on a level surface and added $12 \mathrm{ml} / \mathrm{dish}$ and allowed medium to gel, then were stored plates in closed plastic bags at $4^{\circ} \mathrm{C}$.

Preparations of crude sap obtained from tobacco plants (cv. White Burley) infected leaves of the four virus strains were separately tested against five antiserum $\mathrm{PVY}^{\mathrm{O}}, \mathrm{PVY}^{\mathrm{N}}, \mathrm{PVY}^{\mathrm{C}}, \mathrm{PVY}^{\mathrm{NTN}}$ and universal antiserum for all PVY strains. Crude sap preparation were placed in the peripheral wells after extracted in 3\% SDS and each test antiserum was placed in the control well in a separate plate. Petri dishes were placed in covered plastic boxes to maintain humidity and incubated for 2 days at $25^{\circ} \mathrm{C}$. 


\section{Productivity of potato cultivar Spunta to infected with virus strains}

This work was conducted in open field in the farm of Meit-Kenana, Benha, Qalubia, Egypt to assess the productivity of potato cv. Spunta as infected by virus strains. Field inspections and the collection tubers were done. The tubers which used in this experiment were checked for the freeing from virus infection using DASELISA, 50 tubers were planted separately in open field on 5 lines (each line contains 10 plants). Ten plants of growing potato plants were mechanically inoculated five weeks after planting with each strain and ten healthy plants were left without inoculation as a control. The inoculation process were carried under natural conditions and the potato plants were covered with a transparent plastic sheets, After 120 days the tubers from each potato plant were collected and the weight of tubers were estimated. The reduction of productivity of potato yield as compared to control was calculated as follows:

(The weight of healthy tuber - The weight of infected tuber)

The weight of healthy tuber

X 100

The inoculated plants were tested using DAS-ELISA.

\section{Results}

\section{Incidence of PVY strains affecting potato plants in some governorates}

Field survey studies were conducted during three growing season to study the prevalence and distribution of PVY strains infecting potato in different locations at Behairah, Sharkia and Menoufia Governorates (Egypt) using ELISA test.

Data in Table (3, 4 \& 5) showed that incidence of PVY strains were from (6\%-63.5\%), (4.2\%-67\%) and from $(2.5 \%-36.7 \%)$ during the nile, winter and summer growing season respectively.

232 samples of suspected infected potato plants were collected at the nile growing season. Obtained data presented in Table (3) and Fig. (4) showed that PVY ${ }^{\mathrm{O}}$ was the most prevalent virus being detected in 147 samples followed by $\mathrm{PVY}^{\mathrm{N}}$ in 58 samples and then $\mathrm{PVY}^{\mathrm{C}}$ in 23 samples and finally $\mathrm{PVY}^{\mathrm{NTN}}$ in 14 samples representing $63.5 \%, 25 \%, 9.9 \%$ and $6 \%$ respectively from the whole previously inspected samples.

At the winter growing season, 237 samples showed virus like symptoms were collected. The data presented in table (4) and Fig. (5) Showed that PVY ${ }^{\mathrm{N}}$ had the highest frequency (159 samples, 67\%), followed by $\mathrm{PVY}^{\mathrm{O}}$ (61 samples, $25.7 \%)$, then PVYC $\left(23\right.$ samples, 9.7\%) and finally PVY ${ }^{\mathrm{NTN}}$ (10 samples, 4.2\%).

Out of 79 samples were collected at summer growing season, data presented in Table (5) and Fig. (6) Showed that $\mathrm{PVY}^{\mathrm{N}}$ and $\mathrm{PVY}^{\mathrm{O}}$ had the most prevalent viruses $(29$ samples, $36.7 \%)$, followed by $\mathrm{PVY}^{\mathrm{C}}\left(25\right.$ samples, $^{2}$ $31.6 \%)$ and finally PVY ${ }^{\mathrm{NTN}}$ (2 samples, $\left.2.5 \%\right)$.

Table (1): Occurrence and relative prevalence of PVY strains infecting potato in some producing governorates during the nile growing season.

\begin{tabular}{|c|c|c|c|c|c|c|c|c|c|}
\hline \multirow{2}{*}{$\begin{array}{c}\text { Governorat } \\
\text { es }\end{array}$} & \multirow{2}{*}{$\begin{array}{l}\text { No. of } \\
\text { tested } \\
\text { samples }\end{array}$} & \multicolumn{8}{|c|}{ No. of infected samples } \\
\hline & & $\mathrm{PVY}^{\mathrm{N}}$ & $\%$ & $\mathrm{PVY}^{\mathrm{C}}$ & $\%$ & $\mathrm{PVY}^{\mathrm{O}}$ & $\%$ & $\mathrm{PVY}^{\mathrm{NTN}}$ & $\%$ \\
\hline Behairah & 65 & 46 & 70.7 & 12 & 18.5 & 12 & 18.5 & 1 & 1.5 \\
\hline Sharkia & 68 & 9 & 13.2 & 7 & 10.5 & 50 & 73.5 & 6 & 8.8 \\
\hline Menoufia & 99 & 3 & 3 & 4 & 4 & 85 & 85.8 & 7 & 7 \\
\hline Total & 232 & 58 & 25.0 & 23 & 9.9 & 147 & 63.5 & 14 & 6.0 \\
\hline
\end{tabular}

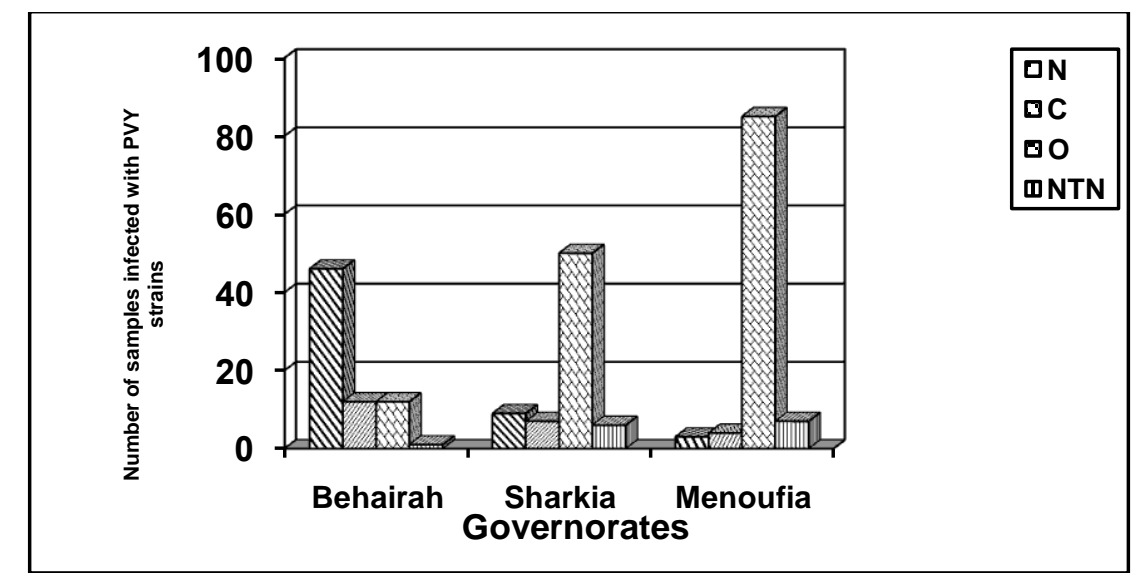

Fig. (1): Diagram illustrated virus strains incidence during the nile growing seas 
Incidence of virus Y Strains and Effect of Infection on the Productivity of Potato Tubers.

Table (2): Occurrence and relative prevalence of PVY strains infecting potato in some producing governorates during the winter growing season.

\begin{tabular}{|c|c|c|c|c|c|c|c|c|c|}
\hline \multirow[b]{2}{*}{ Governorates } & \multirow{2}{*}{$\begin{array}{c}\text { No. of } \\
\text { tested } \\
\text { samples }\end{array}$} & \multicolumn{8}{|c|}{ No. of infected samples } \\
\hline & & $\mathrm{PVY}^{\mathrm{N}}$ & $\%$ & $\mathrm{PVY}^{\mathrm{C}}$ & $\%$ & $\mathrm{PVY}^{\mathrm{O}}$ & $\%$ & $\mathrm{PVY}^{\mathrm{NTN}}$ & $\%$ \\
\hline Behairah & 58 & 40 & 68.9 & 4 & 6.8 & 13 & 22.4 & 1 & 1.7 \\
\hline Sharkia & 60 & 20 & 33.3 & 13 & 21.6 & 32 & 53.3 & 5 & 8.3 \\
\hline Menoufia & 119 & 99 & 83.5 & 6 & 5 & 16 & 13.4 & 4 & 3.5 \\
\hline Total & 237 & 159 & 67 & 23 & 9.7 & 61 & 25.7 & 10 & 4.2 \\
\hline
\end{tabular}

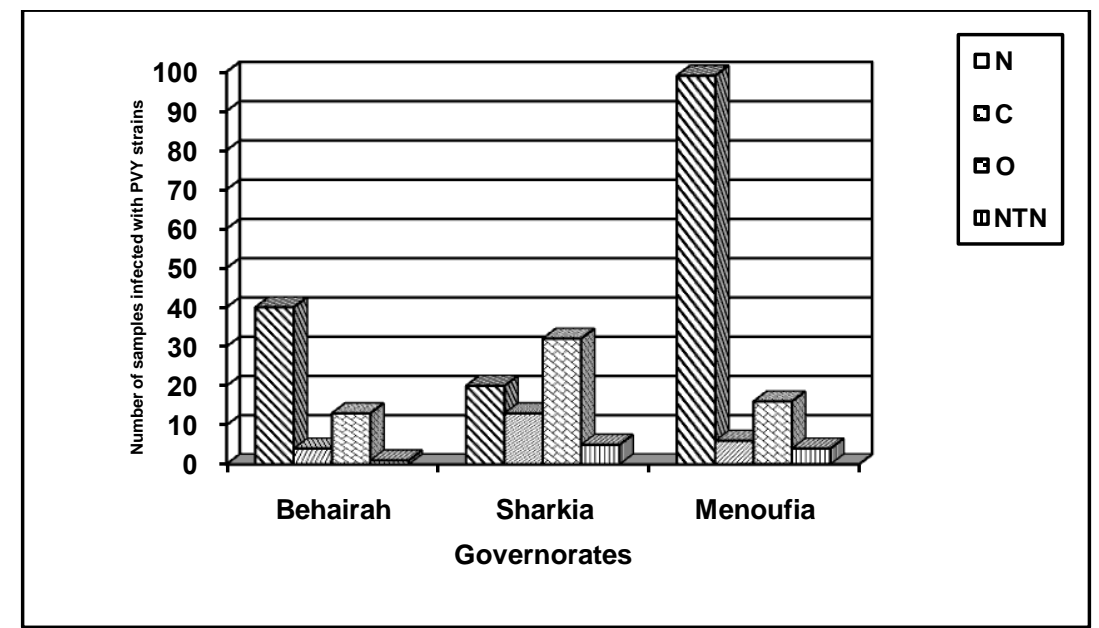

Fig. (2): Diagram illustrated virus strains incidence during the winter growing season.

Table (3): Occurrence and relative prevalence of PVY strains infecting potato in some producing governorates during the summer growing season.

\begin{tabular}{|c|c|c|c|c|c|c|c|c|c|}
\hline \multirow[b]{2}{*}{ Governorates } & \multirow{2}{*}{$\begin{array}{c}\text { No. of } \\
\text { tested } \\
\text { samples }\end{array}$} & \multicolumn{8}{|c|}{ No. of infected samples } \\
\hline & & $\mathrm{PVY}^{\mathrm{N}}$ & $\%$ & $\mathrm{PVY}^{\mathrm{C}}$ & $\%$ & $\mathrm{PVY}^{\mathrm{O}}$ & $\%$ & $\mathrm{PVY}^{\mathrm{NTN}}$ & $\%$ \\
\hline Behairah & 28 & 20 & 71.4 & - & - & 8 & 28.5 & - & - \\
\hline Sharkia & 21 & 5 & 23.8 & 10 & 47.6 & 11 & 52.5 & 1 & 4.7 \\
\hline Menoufia & 30 & 4 & 13.3 & 15 & 50 & 10 & 33.3 & 1 & 3.3 \\
\hline Total & 79 & 29 & 36.7 & 25 & 31.6 & 29 & 36.7 & 2 & 2.5 \\
\hline
\end{tabular}

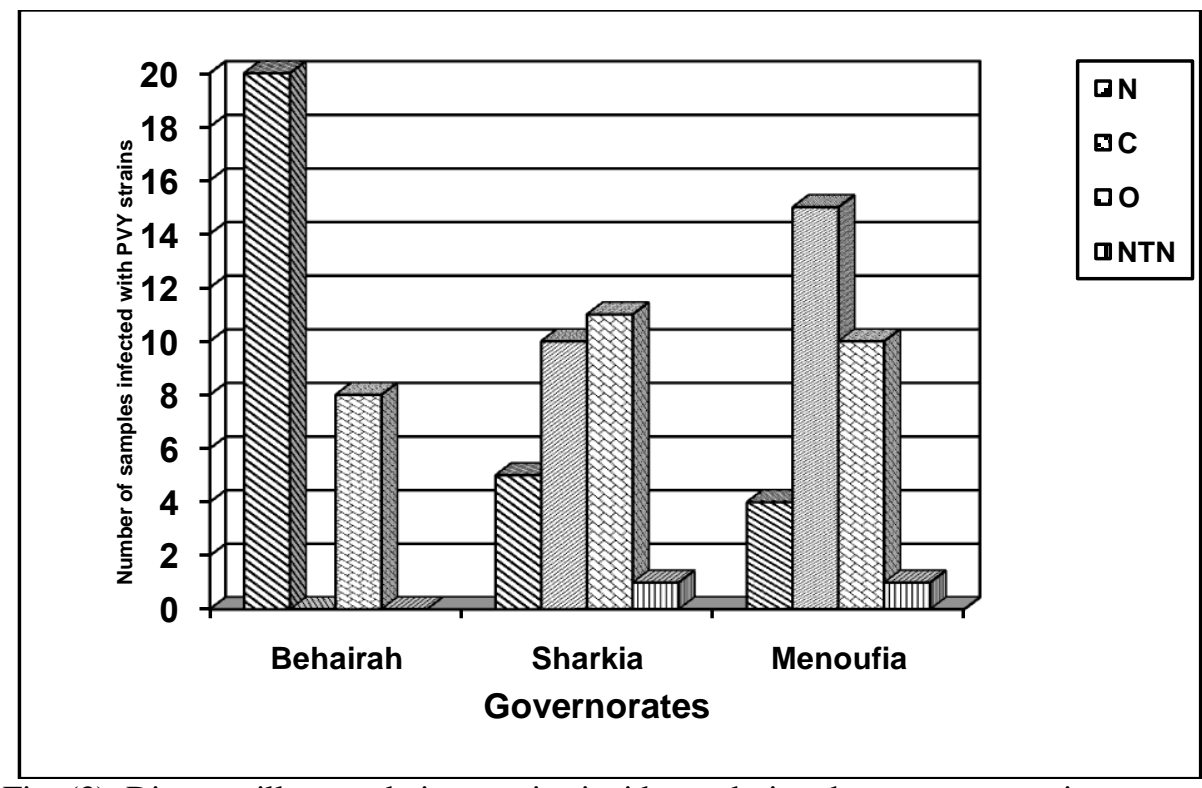

Fig. (3): Diagram illustrated virus strains incidence during the summer growing season. 


\section{Serological detection of PVY strains}

Enzyme linked immunosorbent assay was successfully conducted using monoclonal antibodies (MAbs) were applied to identify PVY strains $\left(\mathrm{PVY}^{\mathrm{O}}, \mathrm{PVY}^{\mathrm{N}} \mathrm{PVY}^{\mathrm{C}}\right.$ and $\left.\mathrm{PVY}{ }^{\mathrm{NTN}}\right)$. The results showed that each strain reacted positively with its specific monoclonal antibodies and reacted negatively with other strains antibody.

Agar double diffusion test was used to confirm the identity of the isolated PVY strains. The Egyptian PVY strains $\left(\mathrm{PVY}^{\mathrm{O}}, \mathrm{PVY}^{\mathrm{N}}, \mathrm{PVY}^{\mathrm{NTN}}\right.$ and $\mathrm{PVY}^{\mathrm{C}}$ ) reacted strongly with the specific antiserum for each strain forming a prominent precipitin line in SDS-double diffusion test (Fig. 4). Also, clear positive reaction was obtained when specific PVY ${ }^{\mathrm{N}}$ antiserum was checked with the sap of PVY ${ }^{\mathrm{NTN}}$ and PVY ${ }^{\mathrm{N}}$. Fig. (4) Showed that antiserum for all PVY strains (universal) reacted strongly with the four tested PVY strains.

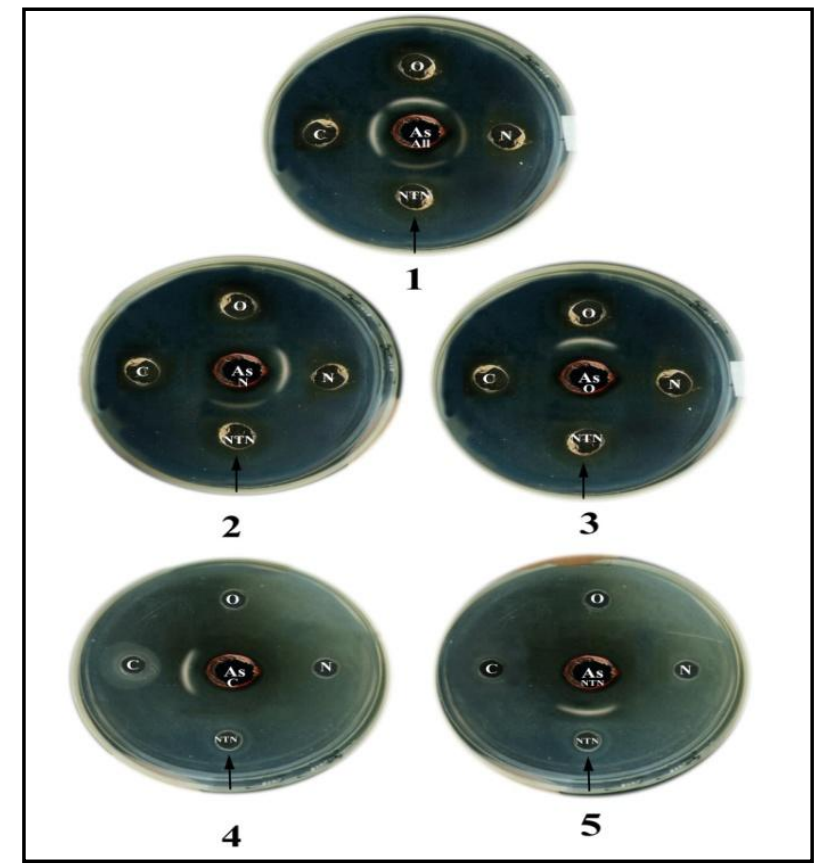

Fig. (4): Serological reaction of PVY strains by the immunodiffusion test; central well contains antiserum of all PVY strains (universal) (1), antiserum of $\mathrm{N}$ strain (2), antiserum of $\mathrm{O}$ strain (3), antiserum of $\mathrm{C}$ strain (4) and the antiserum of NTN strain (5). A positive reaction for PVY ${ }^{\mathrm{N}}, \mathrm{PVY}^{\mathrm{NTN}}, \mathrm{PVY}^{\mathrm{C}}$ (react strongly) and $\mathrm{PVY}^{\mathrm{O}}$ (also react strongly) (1), also positively in $\mathrm{PVY}^{\mathrm{N}}$ (react strongly) and $\mathrm{PVY}^{\mathrm{NTN}}$ (react moderately)

(2). And a positive reaction for $\mathrm{PVY}^{\mathrm{O}}(3)$, gave a positive reaction with $\mathrm{PVY}^{\mathrm{C}}(4)$ and $\mathrm{PVY}^{\mathrm{NTN}}(5)$.

\section{Productivity of potato (S. tuberosum cv. Spunta) infected with virus strains}

Under field condition, the effect of PVY strains infection on the productivity of potato tubers was carried out in Qalubia governorate.

The data showed that, $\mathrm{PVY}^{\mathrm{NTN}}, \mathrm{PVY}^{\mathrm{O}}, \mathrm{PVY}^{\mathrm{N}}$ and $\mathrm{PVY}^{\mathrm{C}}$ - infection decreased productivity of potato tubers by $32.8 \%, 38.5 \%, 50.5 \%$ and $22.6 \%$ respectively compared to control [(Table 4) and (Fig5)].

Table (4): Productivity of potato (S. tuberosum cv. Spunta) infected with PVY strains.

\begin{tabular}{|c|c|c|c|c|c|}
\hline \multirow{2}{*}{ No. of sample } & \multirow{2}{*}{$\begin{array}{c}\text { Productivity of } \\
\text { healthy potato } \\
\text { tubers (gram) }\end{array}$} & \multicolumn{4}{|c|}{$\begin{array}{c}\text { Productivity of infected potato tubers with } \\
\text { (gram) }\end{array}$} \\
\cline { 3 - 6 } & 900 & $\mathbf{P V Y}^{\mathbf{N T N}}$ & $\mathbf{P V Y}^{\mathbf{0}}$ & $\mathbf{P V Y}^{\mathbf{N}}$ & $\mathbf{P V Y}^{\mathbf{C}}$ \\
\hline $\mathbf{1}$ & 920 & 670 & 650 & 430 & 800 \\
\hline $\mathbf{2}$ & 975 & 650 & 675 & 400 & 700 \\
\hline $\mathbf{3}$ & 950 & 630 & 650 & 450 & 730 \\
\hline $\mathbf{4}$ & 1000 & 660 & 560 & 500 & 750 \\
\hline $\mathbf{5}$ & 950 & 650 & 530 & 525 & 825 \\
\hline $\mathbf{6}$ & 900 & 625 & 550 & 500 & 725 \\
\hline $\mathbf{7}$ & 980 & 650 & 570 & 525 & 750 \\
\hline $\mathbf{8}$ & 950 & 725 & 650 & 525 & 750 \\
\hline $\mathbf{9}$ & 1250 & 650 & 625 & 475 & 830 \\
\hline $\mathbf{1 0}$ & 9775 & 6565 & 6035 & 4830 & 7560 \\
\hline Total & & $32.8 \%$ & $38.5 \%$ & $50.5 \%$ & $22.6 \%$ \\
\hline $\begin{array}{l}\text { Productivity } \\
\text { reduction } \%\end{array}$ & & & & & \\
\hline
\end{tabular}




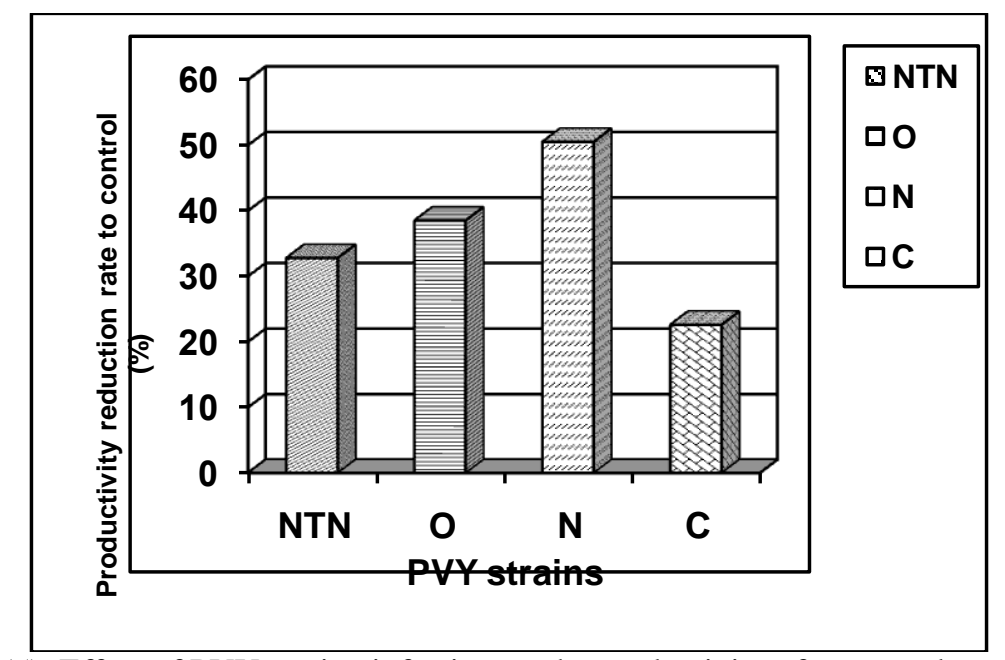

Fig. (5): Effect of PVY strains-infection on the productivity of potato tubers yield.

\section{Discussion}

Field surveys were conducted during three growing seasons to study the prevalence and distribution of PVY strains infecting potato in some locations along three governorates (Behairah, Sharkia and Menoufia) in Egypt. Four strains namely: $\mathrm{PVY}^{\mathrm{N}}, \mathrm{PVY}^{\mathrm{C}}, \mathrm{PVY}^{\mathrm{O}}$ and $\mathrm{PVY}^{\mathrm{NTN}}$ were detected using direct ELISA. These strains were reported in other countries (Blanco-Urgoiti et al., 1998; Takacs et al., 2001; Crosslin et al., 2006) and in Egypt.

The incidence of PVY strains in the collected samples showed virus like symptoms ranged from $(2.5 \%$ to $67 \%$ ) during three growing season. The data showed that, the most prevalent strains were $\mathrm{PVY}^{\mathrm{O}}(63.5 \%)$; $\mathrm{PVY}^{\mathrm{N}}(67.0 \%)$ and $\mathrm{PVY}^{\mathrm{O}} \mathrm{PVY}^{\mathrm{N}}(36.7 \%)$ in nile, winter and summer growing seasons, respectively. Sigh et al. (2003) in surveys of commercial and seed potato fields in Manitoba (Canada) found that, of the samples collected and tested by RT-PCR, 4.0\% contained PVY and further analysis of tested PVY-positive samples by a duplex RT-PCR facilitating the simultaneous detection of $\mathrm{PVY}^{\mathrm{O}}$ and $\left(\mathrm{PVY}^{\mathrm{N} / \mathrm{NTN}}\right)$ indicated that $37.5 \%$ and 63.5\% contained $\mathrm{PVY}^{\mathrm{O}}$ and $\mathrm{PVY}^{\mathrm{N}}$ type isolate, respectively. The obtained results also indicated the high incidence of PVY in nile and winter growing seasons compared with summer growing season. The high incidence in nile and winter growing seasons could be attributed to the fact that farmers during these seasons used their own stored potato tubers, while the low incidence in the farms during the summer growing season may be due to the use of imported and certified potato tubers which are virus-free. The incidence of PVY in summer growing season may be due to the presence of aphids which transmit the PVY strains and also mechanical transmission from susceptible hosts which act as additional reservoirs for these strains.

Potato virus $\mathrm{Y}$ is one of the most important viral diseases of potato worldwide, causing up to $80 \%$ yield losses in several Solanaceous crops (DE Bokx and Huttinga; and Nilesen et al., 1999). The disease is especially serious in areas and in years where large numbers of aphids cause the spread virus infection.

The identity of PVY strains using agar double diffusion test showed that Positive reactions were obtained when specific PVY strains antiserum was checked individually with the sap of infected-PVY strains tobacco leaves.

Results of the effect of infection with PVY different strains on the productivity of potato (S. tuberosum cv. Spunta) were carried out under field condition. The results found that potato plants inoculated with PVY $\mathrm{PVY}^{\mathrm{O}}, \mathrm{PVY}^{\mathrm{N}}$ and $\mathrm{PVY}^{\mathrm{C}}$ showed reduction of productivity reached $32.8 \%, 38.26 \% 50.5 \%$ and $22.6 \%$ respectively when compared to control. Several authors working on PVY indicated that, the infection causes yield reduction of potato reach (50-90\%) by Spaar and Hamann, 1977, (33-77\%) by Sutic et al., 1994 and (10100\%) by Nielsen et al., 1999.

\section{References}

[1] Beczner, L.; H. Horvath; L.H. Romhanyi and H. Foster (1984). Etiology of tuber ringspot disease in potato. Potato Res. 27: 339351 .

[2] Blanco-Urgoiti, B.; F. Sanchez; C. Perez de San Roman; J. Dopazo and F. Ponz (1998). Potato virus Y group (C) isolates are a homogeneous pathotype but two different genetic strains. J. Gen. Virol., 79, 2037-2042.

[3] Chikh, A.; A.V. Karasev; N. Furutani; M. Taniguchi;Y. Kano; M. Sato; T. Natsuaki and T. Maoka (2013) Occurrence of Potato virus $\mathrm{Y}$ strain $\mathrm{PVY}^{\mathrm{NTN}}$ in foundation seed potatoes in Japan, and screening for symptoms in Japanese potato cultivars. British Society for Plant Pathology Article first published online: 25 JAN 2013.

[4] Chrzanowska, M. (1991). New isolates of the necrotic strain of Potato virus Y (PVYN) found recently in Poland. Potato Res., 34: 179-182.

[5] Chrzanowska, M. (1994). Differentiation of potato virus Y (PVY) isolates. Phytopathological Polonica 8: 15-20. 
[6] Clark, M.F. and A.N. Adams (1977). Characteristics of the microplate method for enzyme linked immunosorbent assay for the detection of plant viruses. J. Gen. Virol., 34: 475-483.

[7] Crosslin, J.M.; P.B. Hamm; D.C. Hane; J. Jaeger; P.J. Shiel; P.H. Berger and R.E. Thornton (2006). The occurrence of PVYO, PVYN and PVYN/O strains of potato virus $\mathrm{Y}$ in certified potato seed lot trials in Washington and Oregon. Plant Dis. 90: 11021105 .

[8] DE Bokx, J. and H. Huttinga (1981). Potato virus Y. In Descriptions of plant viruses No. 242. CMI/AAB Descriptions of Plant Viruses. 6 pp.

[9] Galis, L.; C. Kerlan and C. Robaglia (2000). Variability and evaluation of potato virus Y (PVY), the type member of the potyvirus genus. Eurpean J. Plant Pathol. 102: 655-662.

[10] Glais, L.; C. Kerlan and C. Robaglia (2002). Variability and Evolution of potato virus Y. The type species of the potyvirus Genus. In J. A. Khan and J. Dijkstra (Eds.) Plant Viruses As Molecular pathogens. pp. 225-253. Food Products Press ${ }^{\circledR}$. Binghamton. NY.

[11] Gorsane F.; H. Fakhfakh; C. Tourneur; M. Marrakchi and M. Makni (2001). Nucleotide sequence comparison of the 3 terminal region of the genome of pepper veinal mottle virus from Tunisia and Lvory coast. Archives of Virology 146: 611-618.

[12] Hollings, M. and A.A. Brunt (1981). Potyvirus Group. CMI/AAB Descriptions of Plant Viruses, No. 245.

[13] Kerlan, C.; M. Tribodet; I. Galis and M. Guillet (1999). Variability of Potato virus Y in Potato crops in France. Journal of phytopathology 147: 643-651.

[14] Kus, M. (1990). Potato tuberring necrosis disease. In: Abstr. 11th Triennial Conf. of Eur.Assoc. for Potato Res. Ed. In Burgh, Scotland, p. 196.

[15] Le Romancer, M. and C. Kerlan (1997). La maladie des necroses annulaires superficielles des tubercules: une affection de la pomme de terre du au virus Y. Agronomie 11,889-900.

[16] Nielsen, S.L.; M. Nicolaisen; M.L. Hansen; L. Moller; V.J. Hojmark and H. Frederiksen (1999). Potato virus Y. Gron. Viden, Markbrug. No. 211, 6pp.

[17] Ouchterlony, O. (1962). Diffusion in gel methods for immunological analysis II. Progr. Allergy 6: 30-154

[18] Purcifull, D.E. and D.L. Batchelor (1977). Immunodiffusion tests with sodium dodecyl sulfate (SDS) treated plant viruses and plant viral inclusions. Agric. Exp. Station Inst. Food Agric. Sci. Bull. 788, 39pp. Univ. of Florida, Gainserivlle, Florida.

[19] Quintero-Ferrer and A. V. Karasev (2013). First Report of Recombinant Potato virus Y Strains in Potato in Jalisco, Mexico.The American Phytopathological Society, Volume 97 No. 3,P. 430.

[20] Riechmann, J.U.; S. Lain and A.J. Gracia (1992). Highlight and prospects of potyvirus molecular biology. J. Gen. Virol., 73 : 1-16.

[21] Singh, R.P.; D.L. Mc Laren; X. Nie and M. Singh (2003). Possible escape of a recombinant isolate of potato virus Y by serological indexing and methods of its detection. Plant Dis. 87: 679-685.

[22] Spaar, D. and U. Hamann (1977). Kartofel. In: Klinkowski, M. et al., Ed. Pflanziliche Virologie, vol. 3, 3rd edition, AkademicVerlag, Berlin, P. 63-113.

[23] Sutic, D.D.; R.E. Ford and M.T. Tosic (1994). Handbook of Plant virus diseases. CRC Press LLC Boca Raton, Florida, 553 pp.

[24] Takacs, A.; J. Horvath and G. Kazinczi (2001). Some new results on the resistance of wild solanum species to the NTN strain of potato Y Potyuirus 5th Solvenian Conference of Plant Protection, Catez ob Savi 2001. p. 65. 